University of Nebraska - Lincoln

DigitalCommons@University of Nebraska - Lincoln

Agronomy \& Horticulture -- Faculty Publications

Agronomy and Horticulture Department

1988

\title{
Forage Quality and Performance of Yearlings Grazing Switchgrass Strains Selected for Differing Digestibility
}

\author{
Bruce Anderson \\ University of Nebraska-Lincoln, banderson1@unl.edu \\ J. K. Ward \\ University of Nebraska-Lincoln \\ K. P. Vogel \\ United States Department of Agriculture, kvogel1@unl.edu \\ M. G. Ward \\ United States Department of Agriculture \\ Herman J. Gorz \\ United States Department of Agriculture
}

See next page for additional authors

Follow this and additional works at: https://digitalcommons.unl.edu/agronomyfacpub

Part of the Plant Sciences Commons

Anderson, Bruce; Ward, J. K.; Vogel, K. P.; Ward, M. G.; Gorz, Herman J.; and Haskins, Francis A., "Forage Quality and Performance of Yearlings Grazing Switchgrass Strains Selected for Differing Digestibility" (1988). Agronomy \& Horticulture -- Faculty Publications. 308.

https://digitalcommons.unl.edu/agronomyfacpub/308

This Article is brought to you for free and open access by the Agronomy and Horticulture Department at DigitalCommons@University of Nebraska - Lincoln. It has been accepted for inclusion in Agronomy \& Horticulture -Faculty Publications by an authorized administrator of DigitalCommons@University of Nebraska - Lincoln. 


\section{Authors}

Bruce Anderson, J. K. Ward, K. P. Vogel, M. G. Ward, Herman J. Gorz, and Francis A. Haskins 


\title{
FORAGE QUALITY AND PERFORMANCE OF YEARLINGS GRAZING SWITCHGRASS STRAINS SELECTED FOR DIFFERING DIGESTIBILITY ${ }^{1}$
}

\author{
Bruce Anderson, ${ }^{2}$ J. K. Ward, ${ }^{3}$ K. P. Vogel, ${ }^{4}$ M. G. Ward, ${ }^{5}$ \\ H. J. Gorz ${ }^{4}$ and F. A. Haskins ${ }^{2}$ \\ University of Nebraska, Lincoln 68583
}

\begin{abstract}
Switchgrass (Panicum virgatum) is a native, perennial warm-season grass commonly used as summer pasture. Three strains of switchgrass with different in vitro DM disappearance (IVDMD) values were evaluated with yearling cattle (Bos taurus) in three replicated grazing trials All strains were similar in genetic background, maturity and yield potential. 'Trailblazer' (high-IVDMD) resulted in higher $(P<.05)$ ADG than 'Pathfinder' and 'low-IVDMD'. Available forage of Trailblazer had higher IVDMD than Pathfinder and low-IVDMD. The IVDMD differences among strains were similar throughout the season; IVDMD declined between .3 and .5 percentage units per day. Forage availability, CP, NDF and ADF, permanganate lignin and ash were similar among strains. This study documents that plant breeders can select switchgrass plants for higher IVDMD and that strains consisting of progeny of these plants can result in higher animal gains than strains conșisting of progeny of unselected or low-IVDMD plants with similar genetic background, forage yield, maturity, morphology and chemical composition.

(Key Words: Beef Cattle, Pastures, Growth Rate, Plant Breeding, Panicum virgatum, In Vitro Digestibility.)
\end{abstract}

\section{Introduction}

Switchgrass (Panicum virgatum) is a perennial warm-season grass that complements cool-season grasses to improve season-long gains of grazing livestock (Krueger and Curtis, 1979; Matches et al., 1982; Burns et al., 1984). In vitro DM disappearance (IVDMD) can be improved through genetic selection of forage. Burton et al. (1967) increased IVDMD of bermudagrass (Cynodon dactylon) by over $12 \%$ by breeding, which increased ADG by grazing yearling steers by $30 \%$ (Chapman et al., 1972).

Vogel et al. (1981) developed strains of switchgrass that differed in IVDMD by 4.3 percentage units. There were no differences $(P$ $>$.05) among the selected strains in ADF, permanganate lignin, $\mathrm{CP}$ or ash content (Vogel et al., 1984).

\footnotetext{
${ }^{1}$ Journal paper no. 8443. Univ. of Nebraska Agric. Res. Div.

${ }^{2}$ Dept. of Agron.

${ }^{3}$ Dept. of Anim. Sci.

- USDA-ARS.

${ }^{5}$ Present address: Fort Keogh Livest. and Range Res. Sta., USDA, Miles City, MT 59301.

Received October 1, 1987.

Accepted March 24, 1988.
}

Our trials were conducted to determine if genetic improvements in IVDMD of switchgrass would increase gains of beef yearlings grazing switchgrass pastures.

\section{Materials and Methods}

Three grazing trials were conducted at the Agricultural Research and Development Center near Mead, NE on a Sharpsburg silty clay loam soil (fine, montmorillonitic, mesic, Typic Argiudoll). September through August precipitations during the trial were 960,770 and 620 $\mathrm{mm}$ for 1982, 1983 and 1985 , respectively, and high/low temperatures averaged within each year over June, July and August were 29/16, $32 / 17$ and $29 / 15^{\circ} \mathrm{C}$.

Two new switchgrass strains, 'Trailblazer' (formerly called high-IVDMD PC) and 'low IVDMD PC', which had been developed from the same population by one cycle of divergent, restricted phenotypic selection for IVDMD, and a third cultivar, 'Pathfinder', which is similar in yield, maturity and origin (Vogel et al., 1981), were planted during May, 1981. Twelve .4-ha pastures were established in a randomized complete block design with four replicate 
pastures per strain. Atrazine [6-chloro- $N$-ethyl$N^{\prime}$-(1-methylethyl)-1,3,5-triazine-2,4-diamine] at $2.2 \mathrm{~kg} / \mathrm{ha}$ was applied pre-emerge to each pasture. By September, 1981, full stands had developed and many plants were forming seedstalks.

In April of each year, residue from the previous year was burned and $2.2 \mathrm{~kg} / \mathrm{ha}$ of atrazine was applied. In early May, $112 \mathrm{~kg} / \mathrm{ha}$ of $\mathrm{N}$ was applied to each pasture. Pastures were grazed continuously by three randomly alloted beef yearlings/pasture in 1982 and 1983 and by four yearlings in 1985. Angus $x$ Hereford (AH) heifers averaging $303 \mathrm{~kg}$, Simmental $\times$ AngusHereford (SAH) steers averaging $310 \mathrm{~kg}$ and $\mathrm{SAH}$ steers averaging $315 \mathrm{~kg}$ were used in 1982 , 1983 and 1985 , respectively.

Grazing began for the 1982 trial on June 24 when switchgrass was $80 \mathrm{~cm}$ tall and in the fiveto six-leaf stage; grazing continued until September 1 . During this period, many seedstalks developed; grass height eventually exceeded $160 \mathrm{~cm}$. Yearlings were given ad libitum access to water, trace mineral-vitamin mix $^{6}$ and sait. Yearlings were weighed following an overnight shrink without feed or water at the beginning and end of the trial. In 1983 and 1985, grazing began on June 8 and May 31, respectively, when switchgrass was $30 \mathrm{~cm}$ tall and in the four-leaf stage. Grazing was not conducted on one low-IVDMD pasture due to loss of stand caused by saturated soils. Grass height remained between 15 and $50 \mathrm{~cm}$ throughout these grazing seasons. Grazing ended August 9 and July 17 , respectively, when grass height was between 15 and $20 \mathrm{~cm}$ and the herbage remaining was nearly all stem and leaf sheath tissue.

Available forage was estimated weekly by random placement of three $30-\mathrm{cm} \times 182-\mathrm{cm}$ frames within each pasture and clipping the enclosed forage to a $2.5-\mathrm{cm}$ stubble. In addition, forage samples of the top one-third of plants (tops) were collected randomly throughout each pasture concurrently with available forage samples. All forage samples were dried at $50^{\circ} \mathrm{C}$ in a forced-air oven, ground through a mill with a $1-\mathrm{mm}$ screen and subsampled for laboratory analyses.

\footnotetext{
${ }^{6}$ Each kilogram of trace mineral-vitamin mix contained the following: $\mathrm{NaCl}, 110 \mathrm{~g}$ (minimum), $130 \mathrm{~g}$ (maximum); Ca, $110 \mathrm{~g}$ (minimum), $130 \mathrm{~g}$ (maximum); P, $120 \mathrm{~g}$ (minimum); I, $10 \mathrm{mg}$ (minimum); Vitamin A, 45 USP.
}

The IVDMD was measured by the Tilley and Terry (1963) two-stage ( $48 \mathrm{~h}$ each) technique modified to include $1 \mathrm{~g}$ of urea per liter of buffer. The ruminal fluid was a mixture of equal parts collected from two fistulated crossbred steers, one fed a diet of alfalfa (Medicago sativa)-smooth brome (Bromus inermis) hay and the other fed ground corn cobs (Zea mays). Ruminal fluid was mixed with McDougall's buffer (1948) in a 30:70 (v:v) ratio. Crude protein of the switchgrass was determined as $6.25 \times$ Kjeldahl-N (AOAC, 1975). The NDF, ADF, permanganate lignin and ash were determined sequentially (Van Soest and Robertson, 1980).

Yearling gains were analyzed using analysis of variance with individual pastures as the experimental unit, and plant analyses were evaluated as a split-plot in time with pastures as whole plots and sampling period as sub-plots (Steel and Torrie, 1980).

\section{Results and Discussion}

Daily gains of yearlings grazing Trailblazer switchgrass averaged 24 and $14 \%$ higher $(P<$ .05) than of yearlings grazing Pathfinder and low-IVDMD, respectively. Average seasonal gains from the three strains were 351,284 and $299 \mathrm{~kg} / \mathrm{ha}$, respectively, over the three grazing trials (Table 1 ).

Gains during 1982, when grazing began as switchgrass was jointing, were substantially less than during 1983 and 1985 . Yearling catcle demonstrated a distinct preference for top grazing of switchgrass plants prior to the boot stage. They were able to consume forage at nearly the same rate as it was produced, preventing seedstalk development until after grazing was terminated. Switchgrass was in the early boot stage of development when grazing began in 1982, and yearlings were unable to consume the new growth as rapidly as it developed, allowing many seedheads to develop. After panicle emergence, visual observations showed that yearlings almost completely avoided grazing reproductive culms, preferring vegetative culms, new tillers and leaf blades. As a result, forage IVDMD and $C P$ were lower in 1982 than in 1983 and 1985 and NDF, ADF and permanganate lignin content were higher (Table 2). Anderson and Matches (1983) reported that IVDMD and $\mathrm{CP}$ concentration of switchgrass declined rapidly as plants matured to the heading stage and suggested that grazing should begin prior to the boot stage. Thus, low 


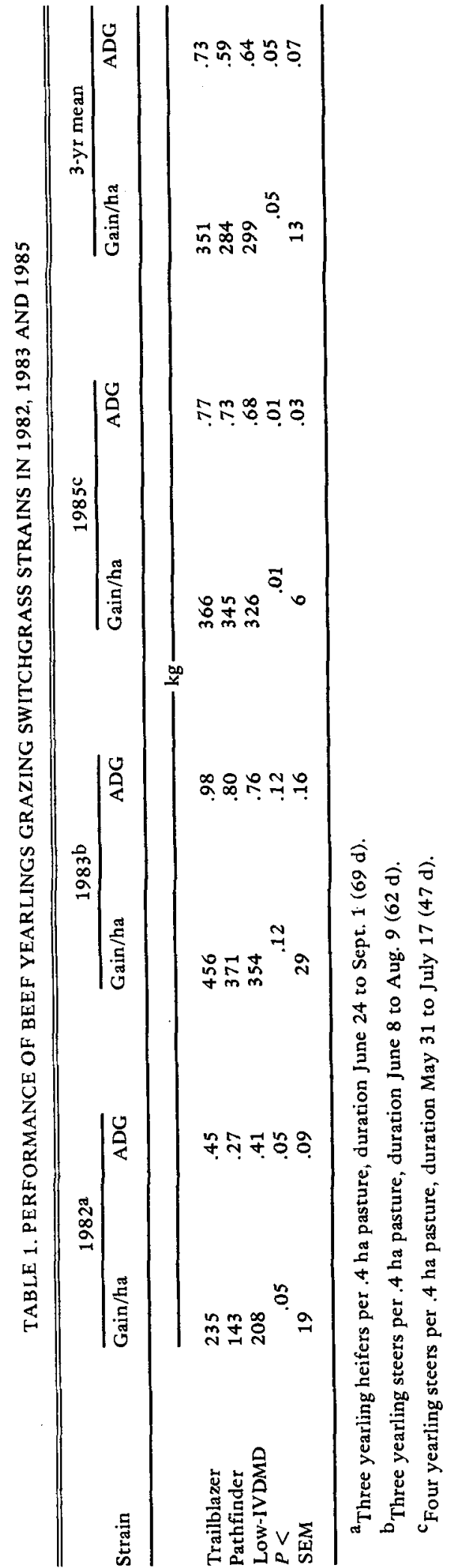

gains in 1982 probably were due to offering yearlings a lower-quality diet, although gain potential probably was lower for $\mathrm{AH}$ heifers than for SAH steers.

Grazing earlier in 1983 and 1985 than in 1982 also reduced forage availability (Table 3 ). Yearlings had twice as much forage available for grazing in 1982 as in 1983 or 1985 . Although increased forage availability often enhances selective grazing, the lower gains in 1982 vs other years suggest that quality of forage was not sufficient to produce as rapid gain in $\mathbf{1 9 8 2}$.

Mean forage availability over the grazing season did not differ among switchgrass strains except in 1985, when Pathfinder averaged 23\% more forage available than Trailblazer and low-IVDMD. In addition, leaf:stem ratios of all three strains were similar in small plots during the vegetative growth stage in early June through anthesis in August (data not shown). Thus, performance differences among strains probably was not due to differences in forage availability.

The IVDMD of all strains declined between .3 and .5 percentage units per day during all three trials (Figure 1); these were similar to declines reported for switchgrass from clipping studies (Anderson and Matches, 1983). Available forage of Trailblazer averaged 1.8 and 2.5 percentage units higher in IVDMD than Pathfinder and low-IVDMD, respectively, and IVDMD averaged 2.5 and 3.7 percentage units higher for tops of Trailblazer than of the other strains (Table 2). When available forage in small plots was harvested at early heading, Trailblazer averaged 4.0 and 4.3 percentage units higher in IVDMD than Pathfinder and low-IVDMD, respectively (Vogel et al., 1984).

Although IVDMD differences were smaller in these grazing trials than in previous clipping studies, Trailblazer was superior consistently to the orher strains. Only in 1983 did IVDMD of available forage of Trailblazer fail to be superior $(P<.10)$ to forage of other strains. The superiority of Trailblazer for IVDMD was consistent throughout the grazing season of all three trials (Figure 1), but all other measured forage components remained similar among strains within each grazing trial (Table 2).

Top grazing was considerable during 1983 and 1985 , so forage samples of the top onethird of plants should have more closely resembled the diet than available forage. Tops generally had higher IVDMD and CP and lower NDF, ADF and ash than did available forage 


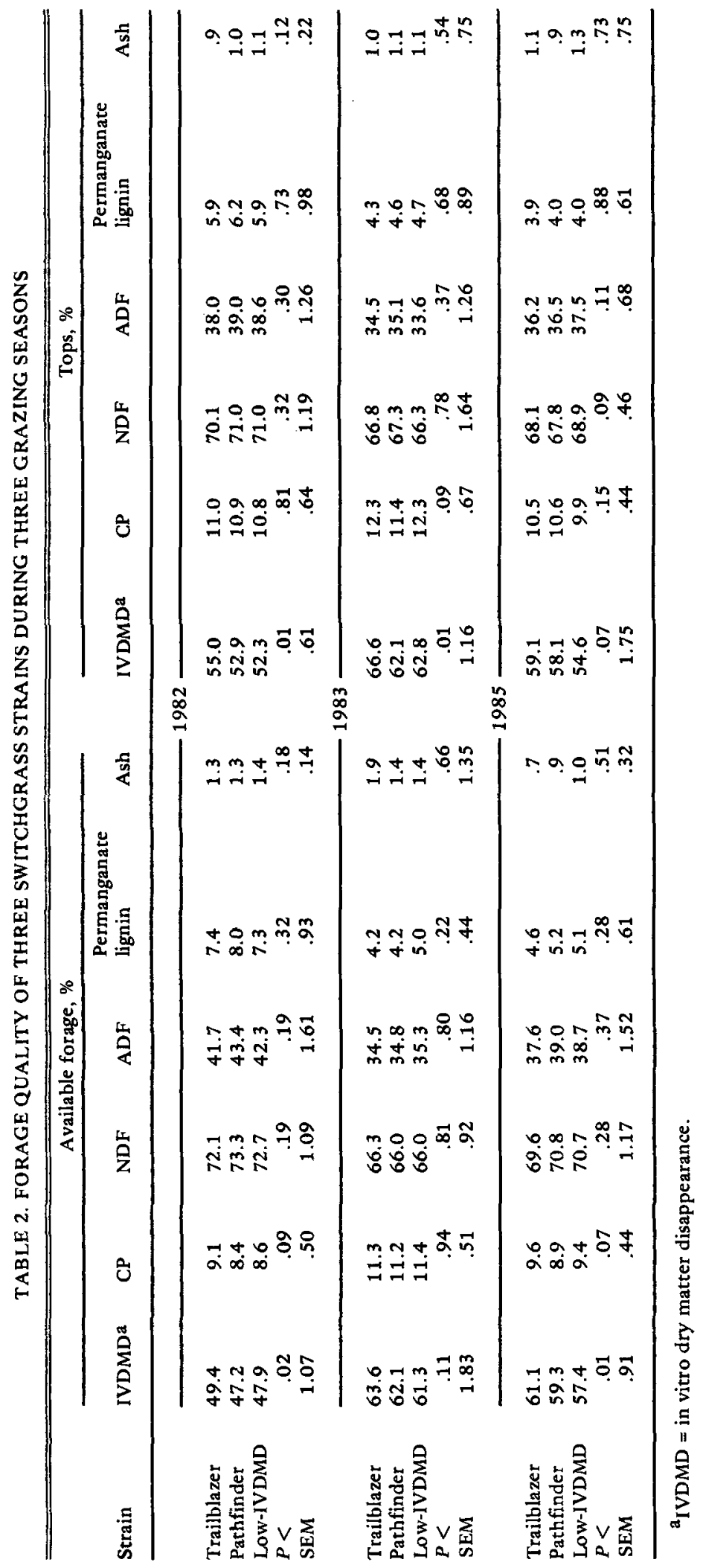




\section{TOPS}

\section{AVAILABLE FORAGE}
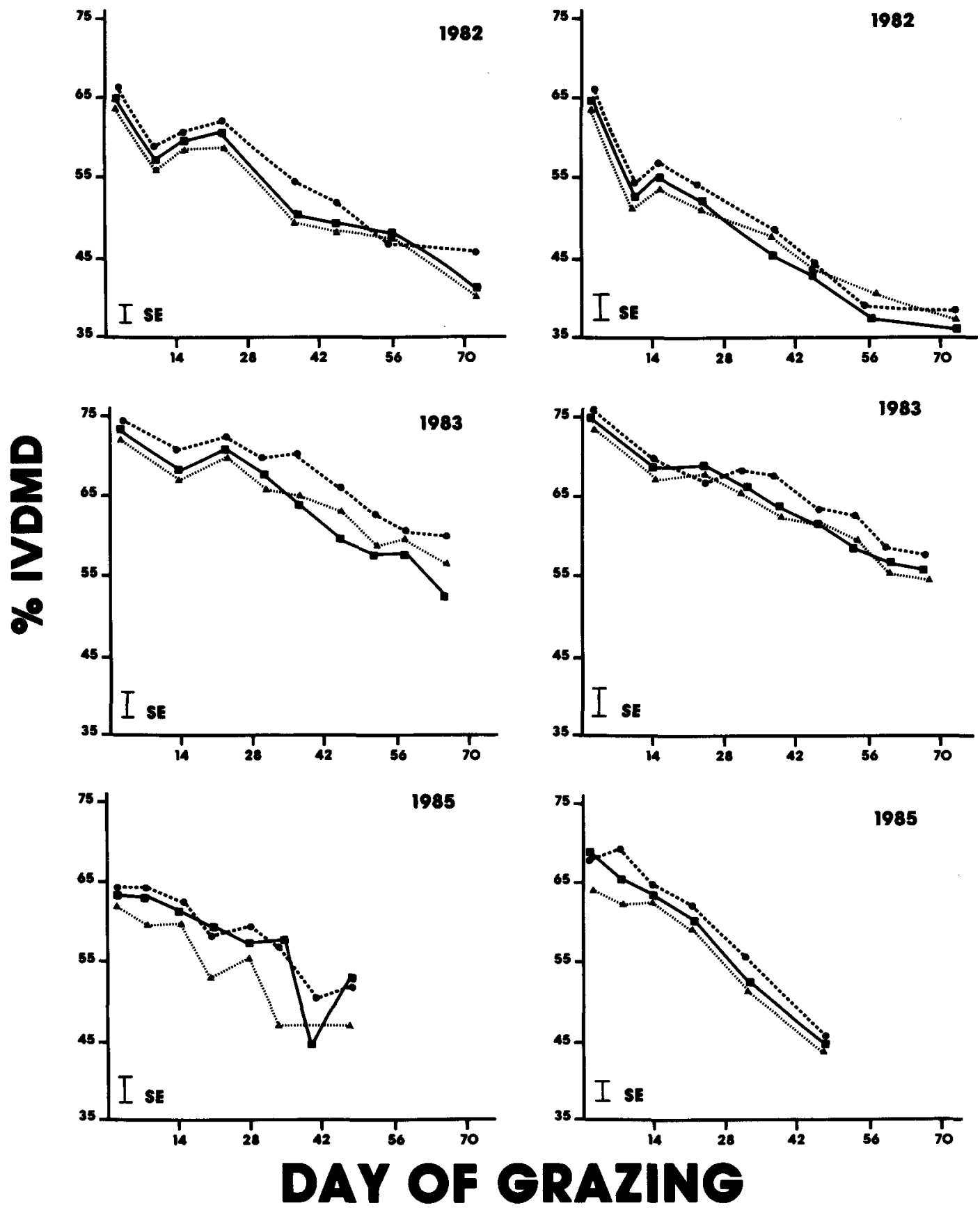

Figure 1. In vitro dry matter disappearance (IVDMD) of available herbage and the top one-third of switchgrass plants in Trailblazer $(\bullet)$, Pathfinder $(\bullet)$ and low-IVDMD $(\triangleleft)$ pastures during 1982,1983 and 1985. SE $=$ standard error of the seasonal mean. 
TABLE 3. MEAN FORAGE AVAILABILITY OVER THE GRAZING SEASON IN SWITCHGRASS PASTURES DURING 1982, 1983 AND 1985

\begin{tabular}{|c|c|c|c|c|}
\hline \multirow[b]{2}{*}{ Strains } & \multicolumn{4}{|c|}{ Mean forage availability } \\
\hline & 1982 & 1983 & 1985 & 3-yrmean \\
\hline Trailblazer & 5,150 & 2,590 & 2,520 & 3,420 \\
\hline Pathfinder & 4,970 & 2,130 & 3,040 & 3,380 \\
\hline Low-IVDMD & 4,800 & 2,280 & 2,410 & 3,160 \\
\hline$P<$ & .78 & .42 & .04 & .61 \\
\hline SEM & 143 & 103 & 71 & 38 \\
\hline
\end{tabular}

due to higher proportions of stem material in available forage samples. The relationships among strains for forage quality, though, were nearly identical for available forage and tops.

Gain responses by yearlings grazing the three switchgrass strains were consistent even though the three trials were conducted under diverse conditions. Neither sex (heifers in 1982, steers in 1983 and 1985), breed cross (AH in 1982 and $\mathrm{SAH}$ in 1983 and 1985 ), stocking density (three yearlings/.4 ha in 1982 and four yearlings in 1985) nor stage of grass maturity at initial grazing (boot in 1982, jointing in 1983 and 1985) altered the relationship among the three strains to cattle gains. Only during 1982 , when low-IVDMD resulted in higher gains than Pathfinder, were gain relationships inconsistent.

Forage IVDMD was the only measured forage component to differ consistently among the three switchgrass strains. Because available forage and yield potential did not differ among the strains, intake presumably was similar. Previous research with bermudagrass showed that digestibility (Burton et al., 1967) and animal gains (Chapman et al., 1972) can be improved by plant breeding. Although in vivo and in vitro measurements of switchgrass digestibility may differ substantially with cattle, the present study documents that switchgrass selected for higher IVDMD can produce plant progeny that result in higher cattle gains than progeny of unselected or low-IVDMD strains with similar genetic background, yield potential, morphology, maturity and forage quality traits such as $\mathrm{CP}, \mathrm{NDF}, \mathrm{ADF}$ and lignin.

\section{Literature Cited}

Anderson, Bruce and A. G. Matches. 1983. Forage yield, quality and persistance of switchgrass and caucasian bluestem. Agron. J. 75:119.

AOAC. 1975. Official Methods of Analysis. Association of Official Analytical Chemists, Washington, DC.

Burns, J. C., R. D. Mochrie and D. H. Timothy. 1984. Steer performance from two perennial Pennisetum species, switchgrass and a fescue 'Coastal' bermudagrass system. Agron. J. 76: 795.

Burton, G. W., R. H. Hart and R. L. Lowrey. 1967. Improving forage quality in bermudagrass by breeding. Crop Sci. 7:329.

Chapman, H. D., W. H. Marchant, P. R. Utley, R. E. Hellwig and W. G. Monson. 1972. Performance of steers on Pensacola bahiagrass, coastal bermudagrass and coastcross- 1 bermudagrass pastures and pellets. J. Anim. Sci. 34:373.

Krueger, C. R. and D. C. Curtis. 1979. Evaluation of big bluestem, indiangrass, sideoats grama and switchgrass pastures with yearling steers. Agron. J. $71: 480$.

Matches, A. G., F. A. Martz, D. P. Mowrey and S. Bell. 1982. Integration of subtropical perennial grasses into forage-animal systems. Agron. Abstr., Am. Soc. of Agron., Madison, WI. p 150.

McDougall, E. I. 1948. Studies on ruminant saliva. I. The composition and output of sheep's saliva. Biochem. J. 43:99.

Steel, R.G.D. and J. H. Torrie. 1980. Principles and Procedures of Statistics. McGraw-Hill Book Co., New York.

Tilley, J.M.S. and R. A. Terry. 1963. A two-stage technique for the in vitro digestion of forage crops. J. Br. Grassl. Soc. 18:108.

Van Soest, P. J. and J. B. Robertson. 1980. Systems of analysis for evaluating fibrous feeds. In: W. J. Pigden, C. C. Balch and M. Graham (Ed.) Standardization of Analytical Methodology for Feeds. pp 49-60. Int. Div. Res. Ctr., Ottawa, Can.

Vogel, K. P., R. Britton, H. J. Gorz and F. A. Haskins. 1984. In vitro and in vivo analyses of hays of switchgrass strains selected for high and low in vitro dry matter digestibility. Crop Sci. 24:977.

Vogel, K. P., F. A. Haskins and H. J. Gorz. 1981. Divergent selection for in vitro dry matter digestibility in switchgrass. Crop Sci. 21:39. 